\title{
Desobediência Civil e Não Violência
}

\author{
José Alcides Renner \\ Doutor em Direito pela Universidad de Deusto/Espanha, \\ professor e coordenador do curso de Graduação em \\ Direito das Faculdades Integradas de Taquara, ex-professor \\ do Programa de Pós-Graduação em Política Social da Uni- \\ versidade Católica de Pelotas. alcides.renner@gmail.com
}

\section{Resumo}

Este artigo trata da não violência, considerada como um dos elementos caracterizadores do conceito de desobediência civil mais insistentemente reclamados na doutrina. Inicia com uma abordagem das dificuldades de conceituar violência e apresenta as diversas espécies de violência, bem como as razões pelas quais se considera que a desobediência civil deva ser não violenta. Distingue, tendo como base o conceito de (não)violência, entre desobediência civil e desobediência revolucionária. 0 problema que o artigo enfrenta, concretamente, é: "Que espécie de violência, ou qual forma de manifestá-la, torna uma desobediência incivil?" Metodologicamente, o estudo parte da análise e da reflexão das concepções de (não)violência de Jean-Marie Muller e de Johan Galtung, para concluir que a violência incompatível com a desobediência civil é a que exclui, elimina ou afasta o oponente na busca das mudanças sociais pretendidas pelo desobediente.

Palavras-chave: Violência. Desobediência civil. Desobediência revolucionária.

\section{Civil Disobedience and Non-Violence}

\begin{abstract}
This paper deals with non-violence as one of the characteristic elements of civil disobedience more insistently claimed in the doctrine. Begins with an approach of the difficulties of conceptualizing violence, presenting different types of violence and the reasons why it is considered that civil disobedience have to be nonviolent. It also distinguishes between civil disobedience and revolutionary disobedience. The question precisely presented is: What kind of violence or in which manner it presents itself becomes a non-civil disobedience? Methodologically this paper follows the analysis and
\end{abstract}


ideas of Jean-Marie Muller's and Johan Galtung's concepts of (non) violence. The paper proposes at the end that the kind of violence that is incompatible with civil disobedience is the one that excludes, eliminates or distances the opponent of the intended social changes.

Keywords: Violence. Civil disobedience. Revolutionary disobedience.

Recebido em: 31/1/2017

Revisões requeridas em: 21/6/2017

Aceito em: 25/9/2017

\section{Sumário}

1 Considerações introdutórias. 2 Sobre o conceito de violência. 3 Por que a desobediência civil deve ser não violenta? 4 Distinção entre desobediência civil e desobediência revolucionária. 5 A violência que descaracteriza a civilidade da desobediência civil. 6 Considerações finais. 7 Referências. 


\section{CONSIDERAÇÕES INTRODUTÓRIAS}

Um dos requisitos exigidos com mais frequência e insistência na literatura para caracterizar uma desobediência ao Direito como civil é o caráter não violento do ato ou da conduta desobediente. Na já clássica definição de desobediência civil de Hugo Adam Bedau, difundida por John Rawls (1997, p. 404, 685, nota 19), a não violência é um de seus elementos conceituais: a desobediência civil, além de ser um ato ilegal, público e consciente, praticado com o objetivo de frustrar leis, programas ou decisões do governo, é um ato não violento. Desobediência civil e violência se excluiriam mutuamente. Desobediência civil violenta seria uma contradictio in terminis.

O que, no entanto, é um ato não violento?

Jorge Francisco Malem Seña (1990, p. 63-72), partindo igualmente da definição de Hugo Adam Bedau, considera que, por se tratar a desobediência civil de atos não violentos, ficam excluídos como tais, desde logo, os atos de sabotagem ou assassinatos que, embora possam ser catalogados como atos de resistência, nunca formariam parte da desobediência civil. Para Malem Seña (1990, p. 72), a não violência exclui como atos de desobediência civil muito mais do que os atos de sabotagem ou assassinatos. Seriam também atos de violência, além da violência física, as ameaças, as coações, a intimidação ou qualquer pressão que restrinja ou elimine a autonomia das pessoas. Nem poderia o desobediente, para poder se caracterizar como civil, praticar a contraviolência, respondendo violentamente aos atos violentos dos agentes do Estado. Deveria, ainda, uma vez condenado, submeter-se às decisões judiciais.

Adotado, no entanto, conceito tão amplo de violência e exigindo-a como requisito para considerar civil uma desobediência, haverá ainda espaço para falar de desobediência civil? Ou, mais incisivamente, os movi- 
mentos liderados por Martin Luther King e Gandhi (tidos pela maioria dos autores como protótipos de movimentos de desobediência civil) ainda podem ser considerados como tal?

Vamos examinar, no presente artigo, ainda que superficialmente, os aspectos mais relevantes referentes ao conceito de violência e sua relação com a desobediência civil, a justificação da incompatibilidade entre violência e desobediência civil, a distinção entre desobediência civil e desobediência revolucionária, para, ao final, a partir das concepções de (não)violência de Jean-Marie Muller e Johan Galtung, propor (novos) parâmetros para conceituar violência, que permitam identificar as formas de violência (in) compatíveis com a tradição da desobediência civil.

Concretamente, nosso problema de pesquisa é: Que tipo de violência torna uma desobediência incivil?

Partindo da ideia central de que a desobediência civil é uma ação política e de que o espaço da política implica o uso da palavra e do diálogo entre os oponentes, nossa hipótese de pesquisa é de que uma desobediência perde seu caráter de civil quando o desobediente exclui o antagonista de sua condição de partícipe na discussão sobre as mudanças sociais propostas, impondo o desobediente as suas soluções.

Metodologicamente, o estudo analisa e reflete sobre as concepções de (não)violência de Jean-Marie Muller e de Johan Galtung, para construir um conceito de (não)violência compatível com a história da desobediência civil.

O tema da desobediência civil, e da civilidade das condutas em geral, é momentoso. As ações de desobediência civil são usadas por diversos movimentos sociais em busca de melhorias sociais, como meio de pressão e participação política. Caracterizar o caráter civil (civilizado) dessas ações de desobediência é uma tarefa que se impõe. Este estudo pretende contribuir com a tarefa, pelo que, parece justificar-se. 


\section{SOBRE O CONCEITO DE VIOLÊNCIA}

A questão da definição de violência e sua relação com a desobediência civil é, efetivamente, muito ampla e complexa. "Como há de definir-se precisamente a violência e a não violência é em si mesmo uma difícil questão filosófica”, escreveu Carl Wellman (1982, p. 30), perguntando em seguida: Atirar um tijolo numa vitrine de loja é um ato violento?

Se manejarmos um conceito muito restrito de violência, limitando-a à utilização ilegítima da força física contra pessoas, podemos afirmar que aquele ato de atirar um tijolo não é violência, e classificá-lo, caso atendidos os demais requisitos, como ato de desobediência civil. Se, no entanto, ampliarmos um pouco aquele conceito de violência para defini-la como a utilização ilegítima da força física também contra coisas, além de contra pessoas, sempre com a intenção de danificá-las ou destruí-las, aquele mesmo ato de atirar um tijolo já seria um ato violento e não poderia mais ser considerado um ato de desobediência civil.

Nas ações dirigidas contra pessoas, entretanto, costuma-se considerar violência não apenas o uso ilegítimo da força, mas também as ações que violam um direito da pessoa: violação do direito à dignidade, do direito de dispor do corpo, do direito de formular os próprios planos de vida, do direito de ver satisfeitas as necessidades da vida, etc. Com isto, se dá entrada a variantes muito importantes de violência: a violência psicológica, a violência estrutural, a violência cultural, que admitem graus variados de intensidade. À medida, todavia, que assim ampliemos o conceito de violência, incluindo as coações, as ameaças e as pressões dirigidas contra as pessoas para que modifiquem seu comportamento ou sua opinião sobre determinado assunto e persistamos na ideia da total incompatibilidade da desobediência civil com a violência, dificilmente encontraremos hipóteses de atos ou condutas que possamos classificar como desobediência civil. Os boicotes, as marchas, as sentadas (sit-ins), as interrupções do trânsito viário e as greves (ilegais), que têm exatamente este propósito de pressio- 
nar a favor de mudanças de pensamento e de rumo a favor de determinada solução posta pelo desobediente como mais adequada à convivência social, não poderiam mais ser consideradas desobediência civil, embora integrem o arsenal de ações de praticamente todos os movimentos de reivindicação.

A questão se complica ainda mais quando consideramos os aspectos emotivos e ideológicos referentes à violência. Jorge Francisco Malem Seña (1990, p. 64) traz à colação, a propósito, o caso do ex-presidente norte-americano Lyndon B. Johnson, que costumava condenar enfaticamente os atos violentos de protesto contra a campanha militar no Vietnam e contra a discriminação racial, enquanto seu governo intensificava a escalada de bombardeios indiscriminados sobre cidades vietnamitas e outras práticas de guerra frontalmente contrárias ao Direito Internacional de Guerra, bem como silenciava sobre a violenta repressão policial contra as manifestações contrárias à guerra e à segregação racial, mesmo quando não violentas. ${ }^{1}$

Um último aspecto a ser enfatizado a propósito do conceito de violência diz respeito às circunstâncias, contingências e situações históricas, culturais e sociopolíticas concretas. É o aspecto estrutural da violência. Johan Galtung (apud MALEM SEÑA, 1990, p. 67) nos propõe o seguinte exemplo para refletir sobre este aspecto da violência: atualmente, com os conhecimentos, condições materiais e recursos médicos e sanitários de

\footnotetext{
${ }^{1}$ De nossa parte, e sem querer estender-nos sobre este aspecto ideológico da questão do conceito de violência, lembraríamos o caso das veementes condenações que certas camadas sociais, políticas e da imprensa fazem, aqui entre nós, da "violência" dos atos de invasão/ ocupação de propriedades rurais por parte de integrantes do Movimento dos Sem Terras, mesmo quando o ato consiste em tão somente cortar o arame das cercas destas propriedades. Com a mesma veemência, se critica também o fato de os integrantes do Movimento levarem consigo crianças e mulheres nas ocupações/invasões, responsabilizando-os pelo risco de sofrerem violência. Estas mesmas camadas sociais, no entanto, praticamente calam a respeito da (violenta) repressão policial, muitas vezes acompanhada pela violência de pistoleiros a serviço dos proprietários rurais, bem como calam sobre a violência da miséria em que vivem estes Sem Terras. Em outra ocasião, com outro artigo, haveremos de ocupar-nos deste Movimento dos Sem Terras e do caráter civil de seus atos de desobediência.
} 
que dispõe a humanidade, a morte de uma pessoa por tuberculose supõe uma situação de violência; não se pode dizer o mesmo da morte de uma pessoa pela mesma enfermidade no século 18 .

O estudioso francês da (não)violência e militante pacifista Jean-Marie Muller² entende que, para conceituar violência, há que começar por aclarar o sentido das palavras conflito, agressividade, luta, força, coação e violência propriamente dita, palavras que frequentemente são confundidas. A seu ver, os homens e os povos, num primeiro momento, experimentam a sua necessária coexistência e convivência de maneira conflitiva, como uma recíproca ameaça, uma adversidade, um transtorno. Experimentada desta forma, a presença do outro, principalmente se ele é diferente, gera medo, ansiedade, insegurança. Em consequência, instintivamente as pessoas costumam ir ao encontro do outro, avançar em sua direção, para se afirmar, para demarcar as respectivas esferas de direitos, para estabelecer as bases de convivência. Este instintivo e natural ir ao encontro do outro é expresso pela palavra agressividade, em seu significado etimológico originário, encontro que não precisa ser violento ou destrutivo. Etimologicamente, na palavra agressão há envolvida tanta violência quanto na palavra progressão: ambas significam tão somente avançar em direção de. A violência seria somente uma das formas de manifestação da agressividade.

Este avançar em direção ao outro pode, no entanto, transcorrer em bases racionais, de diálogo, de mútuas tentativas de convencer ou converter o adversário sobre as condições de uma justa convivência. A partir do momento em que o diálogo não ocorre ou se frustra, se inicia a luta. Para Muller, a função da luta é criar ou restabelecer as condições de diálogo, estabelecendo uma nova relação de forças que obriga ao outro a reco-

${ }^{2}$ Para expor a concepção de (não)violência do autor levamos em consideração sua obra $O$ princípio de não violência. Percurso filosófico. Tradução Maria Fernanda Oliveira. Lisboa: Instituto Piaget, 1998, em especial os capítulos primeiro ("Num mundo de conflitos"), p. 15-28, e segundo ("Reflexão sobre a violência”), p. 29-51. 
nhecer ao primeiro como interlocutor necessário. Este exercício de força para o estabelecimento de novas relações, no entanto, se confunde com o uso da violência. Ao contrário, todas as relações em determinado contexto econômico, social e político se baseiam em uma relação de forças. A injustiça surgiria precisamente do desequilíbrio das forças, pelo qual a força do mais forte oprime o mais fraco. A justiça seria o restabelecimento do equilíbrio por meio do exercício de uma força que imponha um limite à força que introduz o desequilíbrio. A luta contra a injustiça, especialmente contra as injustiças estruturais, teria de valer-se da coação da ação coletiva que seria determinante para o êxito de uma resistência não violenta. A não violência não se reduziria a um simples debate de ideias: ela seria um combate em que se opõem várias forças. A coação serviria para que os oponentes moderem suas ambições e diminuam suas exigências. Em vista do exposto, Jean-Marie Muller (1998, p. 21) pode afirmar que "uma das primeiras tarefas da ação não violenta é mobilizar, isto é, por em movimento, precisamente aqueles que sofrem a injustiça, despertar sua agressividade para prepará-los para a luta, suscitar o conflito”.

A violência, ou a lógica da violência, se iniciaria somente quando os indivíduos, ao rivalizarem por um objeto (ou projeto), desviam sua atenção sobre este objeto (ou projeto) e a dirigem sobre o adversário: quando deixam de desejar o objeto e passam a desejar a eliminação do adversário, ou quando passam a preferir a destruição do objeto de seu desejo ao invés de vê-lo propriedade do adversário. Toda violência encerraria em si um desejo de matar o adversário, que pode não se concretizar, mas a vontade de eliminá-lo, de excluí-lo ou reduzi-lo ao silêncio é mais forte do que a de chegar a um acordo com ele. $\mathrm{O}$ insulto, a humilhação, a tortura, além do homicídio, seriam formas do intento de dar morte, de violentar, de atacar a dignidade do adversário. Para Jean-Marie Muller - e isto reputamos importante para teorizar sobre a violência incompatível com a desobediência civil -, violentar é sempre fazer calar. Privar ao homem de sua palavra já é privá-lo de sua vida. Dizer a alguém que se cale, não 
escutar seus argumentos, excluí-lo da comunidade de diálogo, para usar termos próprios da linguagem da ética discursiva habermasiana, seria uma violência equivalente à de dar morte a este alguém. ${ }^{3}$ Para Muller, mandar calar é ainda pior do que dar morte, porque faz sofrer e o sofrimento seria mais temível que a morte, uma vez que - e aqui Muller se vale de Emanuel Levinas - o ódio não deseja a morte do outro, ou somente a deseja quando puder infligi-la como sofrimento supremo.

A violência seria ainda, para Jean-Marie Muller, uma infração ao imperativo kantiano, de que devemos tratar, nas nossas ações e relacionamentos, a humanidade, tanto em nossa pessoa quanto na de qualquer outro, como um fim, jamais como um simples meio. Como a violência transforma o adversário em objeto, em cadáver ou "em coisa que continua viva”, ela ataca e fere a humanidade tanto de quem a sofre quanto de quem a pratica. Com isto, Muller considera violência tanto as ações violentas diretas e intencionais entre indivíduos quanto as situações de opressão geradas por estruturas políticas, econômicas e sociais, que Johan Galtung chamará de violência estrutural, e que, apesar de que possam não ser intencionais, são evitáveis pelo agir humano, pelo que haverá responsabilidade humana. Considera igualmente violência a contraviolência, a violência da revolta contra a violência opressora, ainda que distinga entre a violência dos opressores e a violência das vítimas da opressão. Em efeito, a violência das vítimas, segundo Muller, normalmente é o meio derradeiro de expressão daqueles a quem a sociedade recusou a palavra. É uma

3 Também para Hannah Arendt (1967, p. 22-23), a violência guarda relação com a imposição do silêncio, razão pela qual deve ser considerada um fenômeno marginal na esfera da política, "puesto que el hombre, en la medida en que es un ser político, está dotado con el poder de la palabra". Onde a violência foi "señora absoluta", diz Hannah Arendt, foi nos campos de concentração dos regimes totalitários, onde não somente se calaram as leis, mas tudo e todos deviam guardar silêncio. 
forma de as vítimas manifestarem sua existência e exigir reconhecimento, ainda que a verdadeira libertação dos oprimidos implique que eles consigam libertar-se inclusive desta sua (contra)violência.

É o professor norueguês Johan Galtung, no entanto, o autor contemporâneo que mais tem contribuído para desvelar a violência como um fenômeno ideológico, cultural e estrutural, e que mais duramente tem fustigado, com seus estudos e análises, a violência como prática nas relações entre pessoas e povos. Galtung é um estudioso, admirador e propagador das ideias e práticas não violentas de Gandhi, além de mediador em inúmeros conflitos violentos mundo afora. ${ }^{4}$

Galtung, baseado na filosofia prática de Gandhi, define a violência como qualquer coisa que possa impedir a autorrealização individual, estancando o progresso de uma pessoa ou atrasando-o. Os obstáculos à autorrealização podem vir tanto da violência direta de atos voluntários de terceiros quanto da violência indireta de ordens sociais injustas - às quais Gandhi certamente dedicava maior atenção, imerso que estava na realidade do colonialismo inglês e do sistema de castas da Índia. Tanto na violência direta quanto na estrutural, os obstáculos à autorrealização devem ser intencionais ou evitáveis. Nesse sentido, os obstáculos atribuíveis à natureza não seriam violentos.

\footnotetext{
${ }^{4}$ Para expor a concepção de Johan Galtung sobre a violência e não violência nos baseamos basicamente no seu livro O Caminho é a Meta: Gandhi Hoje. Tradução Humberto Mariotti. São Paulo: Ed. Palas Athena, 2003. Do mesmo autor, ver também: Paz por medios pacíficos. Paz y conflicto. Desarrollo y civilización. Bilbao: Bakeaz, 2003; e Cadeias de violência: elogio da mediação política. In: Jornal Zero Hora, Suplemento Especial: Forum 2004. Barcelona 9 de maio - 26 de setembro de 2004, p. 28-29. Um resumo das análises e teorias do professor Galtung, incluindo uma tipologia da violência, pode ver-se em MALEM SEÑA, Jorge Francisco. Concepto y justificación de la desobediencia civil. Barcelona: Ariel, 1990. Ver ainda: ETXEBERRIA, Xabier. El lugar del diálogo en la gestión positiva de los conflictos y el caso vasco. Un estudio en el marco de las "Investigaciones sobre paz y conflictos". In: BILBAO Galo et al. Conflictos, violencia y diálogo. El caso vasco. Bilbao: Universidad de Deusto, 2004, p. 31-93.
} 
Por autorrealização deve entender-se o poder de cada pessoa sobre si mesma, poder sempre crescente e adquirido pela vivência em situações conflitivas e por meio da autopurificação, permitindo a progressiva liberação do medo à violência do outro, da dependência econômica e cultural e da submissão ideológica dominadora. A autorrealização leva a pessoa a expandir-se, a transcender-se do "eu pessoal” ao "eu transpessoal”, à "Unidade do homem”, "àquilo que une as pessoas por cima de qualquer conflito”. Esta transcendência não precisa ser traduzida como crença religiosa num Ser Supremo. Pode ser entendida como o sacrifício por uma causa, uma contribuição à família, à sociedade, à humanidade, como a realização de uma vida considerada digna de ser vivida, enfim. Ao definir a violência como um ato obstrutor da autorrealização assim concebida, o praticante do ato violento também se violenta a si mesmo.

A autorrealização ou o poder da pessoa sobre si mesma, entretanto, além de ser impedido violentamente, pode também ser influenciado. Influência, segundo Galtung (2003a, p. 93), "é conseguir que determinada pessoa faça uma coisa e não outra”, fenômeno habitual nas relações humanas. Esta influência pode ser violenta, como nos casos em que se reduzam ou dificultem as opções da pessoa mediante a redução intencional de sua capacidade ou bem-estar biológicos ou de saúde, ou ainda pela redução de seu espaço ou capacidade de percepção, por meio de técnicas de lavagem cerebral ou da ocultação ou deformação intencionais de informação ou de conhecimento.

As influências também podem ser não violentas. Estas Galtung classifica em negativas e positivas. As influências não violentas negativas seriam todos aqueles esforços, à exceção dos que incapacitem corporalmente (que seriam uma influência violenta), que procuram influenciar a outra parte, dificultando-lhe a execução de ações desaprovadas por um 
grupo não violento. Já as influências não violentas positivas seriam as ações ou medidas não violentas dirigidas a facilitar ou estimular as ações do adversário desejadas pelo grupo não violento.

Galtung utiliza a educação das crianças como exemplo para clarificar os conceitos expostos. Para influenciar as ações das crianças, ou evitar "sua infeliz tendência” de arrancar páginas de livros, uma opção violenta seria bater nelas ou castigá-las fisicamente, pois estas ações interferem na saúde ou bem-estar biológico da criança. Uma opção não violenta negativa seria pôr os livros fora do alcance da criança, e oferecer um outro brinquedo ou outros livros com ilustrações interessantes, ou, inclusive, ensiná-la a usar os livros como tijolos de construção; seriam opções não violentas positivas. Galtung está convencido que, normalmente, as ações não violentas positivas funcionam melhor, formando crianças e adultos mais criativos e audazes. Os métodos negativos, ao contrário, formariam indivíduos conformistas e assustados, ainda que, às vezes, possam ser necessários. Para ele, é difícil passar da violência à não violência e da não violência negativa à não violência positiva. Fazer ambas as coisas seria o ideal, mas, afirma Galtung, não se pode permitir que o melhor bloqueie o caminho do bom. ${ }^{5}$

${ }^{5}$ A concepção de violência, não violência negativa e não violência positiva do professor Galtung sucintamente exposta, guarda coerência com sua preocupação com as culturas e as estruturas sociais, políticas e econômicas, nacionais e internacionais, que, mais que os atores individuais ou coletivos, impedem ou obstaculizam uma maior realização dos direitos humanos e a satisfação das necessidades humanas, sendo, portanto, a causa mais profunda da violência (GALTUNG, 1998, Cap. IV). Faltaria, na verdade, pôr efetivamente em prática o artigo 28 da Declaração Universal dos Direitos Humanos: "Todo ser humano tem direito a uma ordem social e internacional em que os direitos e liberdades estabelecidos na presente Declaração possam ser plenamente realizados”. Segundo nosso autor, no entanto, os sistemas jurídicos costumam privilegiar, em suas disposições e sanções, aos indivíduos, corporações e governos, certamente porque são mais visíveis e facilmente identificáveis, com o que as estruturas e culturas que provocam ou subjazem às ações e condutas dos agentes mencionados ficam sem serem processadas/condenadas. Assim, em relação à tortura, "existe uma estrutura para a tortura, não só a nível nacional, mas também internacionalmente. Uma tradição de direitos humanos relevante tem certamente que condenar a tortura e proteger a vítima. Mas tem também que condenar as estruturas que produzem 
A não violência é, portanto, mais do que não causar dano, e tende a uma atitude positiva, construtiva. O que Galtung não cansa de enfatizar é a preocupação gandhiana pelo antagonista. O objetivo do lutador social não violento deve ser a destruição das estruturas sociais e econômicas opressoras e a violência direta que impede a autorrealização das pessoas, sem, não obstante, destruir ou humilhar o antagonista ou impedir a autorrealização dele. A resolução não violenta positiva dos conflitos nos obrigaria, inclusive, a auxiliar o antagonista nas dificuldades que nossas ações de combate e de não cooperação com a estrutura ou atividade consideradas injustas possam ocasionar-lhe. O ideal da não violência positiva recomenda que as condições coercitivas nunca representem uma capitulação do oponente. Haveria que se empenhar no sentido de persuadi-lo de seu erro e convidá-lo a participar das estruturas sociais e econômicas propostas. Haverá, todavia, ocasiões - em relação a uma convicção ou conduta manifestamente contrária aos direitos humanos, por exemplo - em que a não violência negativa da capitulação seja a melhor possível. Ainda que somente a conversão do antagonista produza resultados duradouros, há situações em que certas imposições, se possível transitórias, se justificam desde concepções não violentas.

A partir das concepções de (não)violência expostas, que relação elas guardam com a desobediência que se quer civil/civilizada? Que tipo de (não)violência é (in) compatível com a desobediência civil? Em que

\footnotetext{
a tortura e proteger aqueles que tentam revelar e demolir essas estruturas. O direito de não ser torturado é básico, mas também superficial. O direito mais profundo seria o direito humano a viver numa estrutura social e mundial que não produzisse tortura. Obviamente, os dois não se excluem mutuamente" (GALTUNG, 1998, p. 204). O Caminho para a paz, para Galtung, passa pela resolução criativa dos conflitos, o que significaria transformar, uma vez mais, as estruturas e culturas de violência em culturas de paz. Punir somente os agressores, embora seja necessário, não resolve os conflitos, "ao contrário, provavelmente os congela e legitima a violência” (1998, p. 213).
} 
momento, em relação aos métodos de ação, uma desobediência passa a não ser mais civil para se transformar em revolucionária ou criminosa (comum)?

Antes, no entanto, vamos examinar as razões pelas quais a doutrina costuma exigir que a desobediência civil seja não violenta.

\section{POR QUE A DESOBEDIÊNCIA CIVIL DEVE SER NÃO VIOLENTA?}

Juan Ignácio Ugartemendia Eceizabarrena (1999, p. 155) enumera as seguintes razões pelas quais a doutrina costuma reclamar a não violência da desobediência civil:

1) a não violência tem formado parte da tradição da desobediência civil, associada principalmente às principais figuras de sua história, Gandhi e Luther King;

2) o abandono da violência pelo desobediente civil na consecução de seus fins é um sinal tangível da seriedade destes fins, principalmente quando o desobediente não oferece resposta à violência dos outros;

3) a renúncia da violência é uma prova do compromisso do desobediente civil com a legitimidade do sistema social e político, manifestando uma deliberada rejeição aos meios ilegítimos para alcançar os fins;

4) se os desobedientes civis querem comunicar, educar e persuadir sobre determinada questão, o uso da violência poderia criar um efeito contrário, provocando que se rejeite ou dilua o objetivo último do protesto. ${ }^{6}$

${ }^{6}$ Em palavras semelhantes, e em reforço à última das razões aduzidas, assim se expressou Nelson Nery Costa (2000, p. 57): "Os movimentos mantidos num clima pacífico e ordeiro facilitam a avaliação favorável do público em geral quanto à procedência das reivindicações”. 
Há que salientar, no entanto, por um lado, que os autores, quando afirmam a total incompatibilidade da violência com a desobediência civil, têm em vista, como regra geral, um conceito muito restrito de violência, não incluindo as pressões e as coações sobre os oponentes como violência. Desta forma, estes autores podem classificar as ações de Gandhi e Luther King como desobediência civil, embora normalmente estas ações envolvessem considerável pressão ou coação sobre os adversários. ${ }^{7}$ Além disto, há formas de violência, quando a consideramos em termos bem amplos, que podem favorecer os propósitos do desobediente de expressar a seriedade dos fins perseguidos (item 2), bem como de manifestar compromisso com o sistema social e político (item 3), como veremos mais adiante.

Por outro lado, as razões indicadas para propugnar a não violência dos atos ou condutas desobedientes civis, mais do que propriamente caracterizar a desobediência civil, delimitando-a de figuras que lhe são próximas, indicam tipos específicos (ou classificações) de desobediência civil: uma desobediência civil justificada moral ou juridicamente, nos três primeiros casos, e uma desobediência civil eficaz, no caso do item 4. Em outras palavras, estaria-se confundindo definição com justificação, isto é, como em princípio há dificuldades em justificar moral e juridicamente a violência e como o objetivo é justificar a desobediência civil, termina-se por incluir entre os requisitos desta a não violência. Assim também em relação

\footnotetext{
${ }^{7}$ É conhecida a preocupação de Gandhi com a pressão e coação que suas ações exerciam sobre seus adversários. Seu biógrafo, George Woodcok (1995, p. 78-81), recorda certa campanha de demanda por melhorias salariais liderada por Gandhi no interior da Índia, na qual, depois de diversos dias de paralisação (greve), os ânimos dos trabalhadores estavam prestes a ceder, em vista da falta de quaisquer avanços na negociação e da falta de dinheiro para a compra de comida. Para uni-los e estimulá-los a lutar até o final, Gandhi iniciou uma greve de fome, apesar de sua débil saúde. Imediatamente, os proprietários, entre os quais havia muitos amigos seus, acederam a negociar. Nas suas reflexões sobre o episódio, Gandhi lamenta a coação que sua greve de fome havia exercido sobre os proprietários, justificando-a, todavia, como medida necessária para a purificação e aperfeiçoamento dos demandantes. $\mathrm{O}$ objetivo primeiro, dizia, era a persuasão dos patrões mediante o sofrimento pela verdade dos grevistas, no qual incluía seu próprio sofrimento; a coação era um efeito secundário não desejado.
} 
com a eficácia. Tendo em vista que o objetivo da desobediência civil é alcançar alguma modificação social e se este objetivo pode ser prejudicado pelo uso da violência, passa-se a exigir, como requisito da desobediência civil, a não violência. Neste último caso, no entanto, a não utilização da violência é meramente estratégica. Utiliza-se ou não a violência em razão dos resultados que se perseguem.

A utilização estratégica da violência por parte dos desobedientes civis pode dar-se de diversas formas. Uma delas é os desobedientes provocarem, explicitamente, por meio de suas ações, a violência contra si, para utilizá-la estrategicamente. Como exemplo pode-se citar "a desobediência civil promovida por certos grupos radicais, como alguns movimentos pacifistas ou o Black Power" (COSTA, 2000, p. 56), que instigam os grupos de interesses dominantes a utilizar a violência contra eles para deslegitimar seu poder, uma vez que, ao utilizar a violência, este poder estaria demonstrando que se mantém por causa dela e não pelos ideais e valores que defende ou diz defender. Por outro lado, há os que suportam sofrer a violência contra si (pequena) como forma de fazer manifesta uma violência oculta (estrutural, cultural) muito maior. É o célebre exemplo dos desobedientes civis, conhecidos como apóstolos da não violência, Gandhi e Luther King. Ambos não provocavam expressamente a violência e a consideravam um mal em si, mas ainda assim viam algum benefício nela, sofrendo-a. Gandhi entendia que padecer a violência ou outros sofrimentos e privações, além de servir para purificar o desobediente civil, podia, aliado à consciência ou sentido de justiça do opressor, persuadir o adversário, convertendo-o a favor da causa do desobediente civil. Martin Luther King defendia a pública exposição da violência (mediante os meios de comunicação) que sofriam os integrantes dos movimentos pelos direitos civis para ganhar a simpatia da opinião pública a favor da causa. 
Um argumento que parece excluir os atos violentos como desobediência civil é o gandhiano, da coerência entre meios e fins, em linha com a concepção de não violência de Galtung antes exposta. Na interpretação que este autor faz de Gandhi (GALTUNG, 2003a), a própria separação entre fins e meios deveria ser rejeitada, porque "meios e fins são uma mesma coisa: se estendem no tempo e não estão separados em dois segmentos temporais" (p. 106). A seu modo de ver, o satyagraha gandhiano não é uma técnica que pode ser separada de sua finalidade, a de perseguir uma sociedade menos violenta. Resultados e ações se contaminam mutuamente: fins não violentos não santificam meios (violentos), nem meios não violentos santificam fins (violentos); se um dos lados desta unidade é violento, a totalidade o será.

Gandhi (1998, p. 129-133) efetivamente entendia que há uma relação intrínseca e indissolúvel entre meios e fins. Esta relação seria a mesma que existe entre a semente e a planta. Por isto, para ele, o raciocínio dos adeptos da escola da violência e o dos anarquistas no sentido de acreditarem que é possível alcançar causas nobres por métodos violentos, seria similar ao dos que creem que é possível colher uma rosa semeando ervas daninhas. Um objetivo alcançado por meios violentos nunca seria igual ao alcançado por meios não violentos. Além disto, é por intermédio dos meios que daríamos a conhecer aos adversários os fins desejados. Os meios, na verdade, corporificam os fins.

Assim, o desobediente civil, ao lutar por uma sociedade mais justa, menos violenta, na qual todos possam autorrealizar-se, haveria que começar praticando-a aqui e agora.

\section{DISTINÇÃO ENTRE DESOBEDIÊNCIA CIVIL E DESOBEDIÊNCIA REVOLUCIONÁRIA}

Uma questão que está relacionada com a violência é a da distinção entre desobediência civil e desobediência revolucionária. Em efeito, os dois critérios mais utilizados pela doutrina para distinguir entre desobedi- 
ência civil e desobediência revolucionária são o uso ou não da violência e a radicalidade da mudança pretendida. Em relação à violência, a desobediência civil não admitiria o seu uso, enquanto a desobediência revolucionária a admitiria, quando não a pressupõe. Ambos os fenômenos - a violência e a radicalidade da mudança - teriam estado presentes, de maneira exemplar, na Revolução francesa. Assim, para Ugartemendia Eceizabarrena (1999, p. 175), será a partir da Revolução Francesa que o vocábulo revolução "se asociará de forma casi indisoluble a una idea de cambio, de transformación estructural radical, de rechazo del orden jurídico-político y de instauración de un novus ordo, llevada a cabo normalmente de una forma violenta y procelosa [intensa, profunda]". ${ }^{8}$

As dificuldades que antes comentávamos, de consensuar uma definição de violência e de fundamentar a exigência da não violência como requisito caracterizador da desobediência civil, naturalmente transferem-se ao problema da distinção entre as duas figuras - a desobediência civil e a desobediência revolucionária -, quando baseadas neste critério da (não) violência. Assim, uma concreta ação de infração deliberada da legalidade vigente será desobediência civil ou revolucionária em virtude da definição de violência que manejemos. Se definimos a violência muito amplamente, parece que haverá que admitir como civis desobediências com alguma violência.

\footnotetext{
${ }^{8}$ A radicalidade da mudança ou da rejeição da ordem jurídico-política vigente e a utilização da violência são também elementos que integram a definição de revolução proposta por Herbert Marcuse, que agrega, no entanto, outras características mais. Com efeito, para Marcuse (apud MALEM SEÑA, 1990, p. 92), revolução seria “el derrocamiento de un gobierno y de una constitución legalmente establecidos por una clase social, o un movimiento, cuyo fin es cambiar la estructura social y la estructura política. Esta definición excluye todos los golpes de estado militares, revoluciones de palacio y contrarrevoluciones preventivas - como el fascismo y el nacionalsocialismo - porque no cambian la estructura social básica. Si definimos la revolución de esta manera, podremos dar un paso más y decir que este tipo de alteración radical y cualitativa incluye la violencia”. Uma ampla tipologia, análise e distinções das diversas figuras políticas de resistência à ordem jurídica, assim como a indicação de uma extensa bibliografia referente ao assunto, pode ver-se em Juan Ignacio Ugartemendia Eceizabarrena (1999, p. 174-182).
} 


\section{A VIOLÊNCIA QUE DESCARACTERIZA A CIVILIDADE DA DESOBEDIÊNCIA CIVIL}

Voltando a valer-nos de Johan Galtung (apud MALEM SEÑA, 1990, p. 95-96), podemos afirmar que as pessoas, quando e enquanto se encontram imersas em uma situação de diálogo, como é próprio das relações de convivência social, estão sujeitas a uma "interinfluência recíproca". Também esta interinfluência, tal como examinado anteriormente em relação à influência sobre a conduta de uma pessoa, pode ser levada a cabo de duas maneiras: uma negativa e outra positiva. A interinfluência será negativa se uma das partes impede a ação comunicativa da outra, e será positiva se "favorecer o surgimento de novos cursos de ação" para o diálogo ou se tornarem mais atraentes os cursos de ação já existentes. Esta interinfluencia positiva não seria violência. "Portanto - diz Galtung definimos a violência como qualquer atividade que pretende reduzir a ação ou o espaço dos seres humanos impedindo suas ações, e a não violência como qualquer atividade que pretende ampliar a ação e o espaço dos seres humanos incluindo novas ações ou tornando-as mais atraentes”.

A partir da definição de (não)violência proposta por Galtung, podemos considerar como não violentas aquelas ações destinadas a dramatizar uma determinada situação ou para comunicar ao oponente - autoridades ou maiorias que as apoiam - como os seus atos - políticas, normas ou ações governamentais - estão sendo percebidos. Assim, não seriam violentas e, portanto, seriam compatíveis com a desobediência civil, se preenchidos os demais requisitos da figura, todas aquelas ações (ilegais) destinadas a reforçar ou sublinhar a mensagem dirigida às autoridades (ou às maiorias que as apoiam), ou a solidez das convicções ou o estado de ânimo de quem emite a mensagem. Como exemplos podem citar-se os piquetes, as sentadas (sit-ins), as obstruções, as greves políticas (ilegais), as ameaças (principalmente as de não cooperação), etc., acompanhadas ou não de ações e situações de sofrimento autoinfligido, como permane- 
cer, ainda que não obstruindo a passagem, longas horas de pé ou sentado diante de instalações públicas ou de fluxo intenso de pessoas em condições adversas de tempo, realizar longas e penosas caminhadas, enfrentar situação de perigo, etc.

Desta forma, grande parte das ações historicamente praticadas pelos desobedientes civis, como as citadas e outras, não implicariam violência, desde que sirvam e favoreçam o diálogo, no sentido de oferecerem novos temas ou novos ângulos dos temas em debate, de ampliarem o diálogo em termos subjetivos - introduzindo novos atores que estavam até então excluídos - e objetivos - aduzindo novos assuntos ou enfoques distintos dos temas em debate. Ao contrário, seriam violentos e incompatíveis com a desobediência civil aqueles atos que privam o adversário de possíveis cursos de ação a seguir. Seriam violentos, em suma, os atos que supõem, por seus métodos e/ou objetivos, não uma apelação ao sentido de justiça da maioria, do governo, para que modifiquem suas posturas uma tentativa de convencer e converter -, mas a exclusão do oponente com a imposição da solução pretendida, realizando os próprios agentes (desobedientes) a mudança reivindicada.

A violência assim concebida é efetivamente incompatível com a civilidade da desobediência civil, além de ser ético-politicamente incorreta, principalmente à luz da teoria da ação comunicativa da ética discursiva habermasiana. Com efeito, segundo esta teoria - cuja relação e fundamentação para a desobediência civil haveremos de tratar em outra oportunidade -, o estabelecimento das estruturas sociais e suas regras de funcionamento legítimas, reguladoras da convivência social e merecedoras de obediência, hão de ser fruto de convicções compartidas, aceitas consensualmente depois de submetidas a debates e deliberações públicas. Estes debates e deliberações hão de estar regidos por um procedimento objetivo, imparcial e razoável, desenhado a partir do modelo ideal da situ- 
ação de fala, isto é, pela busca cooperativa da verdade e da correção, sem exclusão de argumentos ou participantes, orientados estes tão somente pela força/coação do melhor argumento.

Neste processo dialógico de estabelecimento de estruturas sociais e regras de regulação da convivência social, as ações e situações definidas por Galtung como violentas, como a exclusão de argumentos e/ou de participantes ou a imposição de propostas - "interinfluência negativa” em palavras de Galtung -, não cabem e devem ser evitadas ou removidas sem violência. Podemos considerar compreendidas nesta categoria de ações e situações, além da violência clássica contra a pessoa, a começar, por óbvio, pela mais radical, a ação de eliminar o antagonista, as formas mais sutis de violência, a de humilhá-lo, de desprezá-lo e constrangê-lo física e psiquicamente com o objetivo de impedir ou diminuir o valor dos seus argumentos ou a própria participação comunicativa dele na busca das melhores soluções para a convivência. A mencionada categoria compreenderia igualmente as violências estruturais que impedem ou dificultam o diálogo entre iguais - situações graves de pobreza e ignorância, por exemplo - assim como a transformação do diálogo sincero da busca cooperativa da verdade e da correção em interações linguísticas estratégicas, mentindo ou ocultando informações e objetivos, por exemplo. Não estariam excluídas, no entanto, certas pressões ou coerções inerentes ao diálogo ou que conduzam a ele, com o objetivo de apresentar e especificar a mensagem, de ampliar o universo deliberativo e o conjunto de opções de solução do conflito, de dobrar resistentes ou resistências empedernidos, de despertar consciências adormecidas, etc. - a "interinfluência positiva”, em palavras de Galtung. ${ }^{9}$

${ }_{9}^{9}$ Nesse mesmo sentido, Jürgen Habermas (1997, p. 56), principal mentor e teórico da Ética Discursiva, considera que a não violência da desobediência civil se traduz principalmente pelo caráter simbólico da infração jurídica, isto é, o desobediente não pretende, com sua 
Para distinguir entre a "interinfluência negativa" e a "interinfluência positiva”, como facilmente se percebe, o objetivo com o qual se pratica a ação é decisivo. $\mathrm{Na}$ “interinfluência positiva” há atenção com o adversário, cujo bem-estar, desenvolvimento e contribuição ao debate são buscados e considerados necessários para a legitimidade das soluções encontradas, contemplando-se, assim, a preocupação gandhiana com o antagonista. Já na "interinfluência negativa”, a intenção é eliminar ou excluir o oponente da participação, ou diminuir sua importância. Nos casos práticos, certamente haveremos de tropeçar em muitos obstáculos para delimitar precisamente entre "interinfluências negativas" e "interinfluências positivas”, dificultando, consequentemente, nossas distinções entre desobediências civis e não civis, mas o norte está dado: a comunidade ideal de comunicação, desenvolvida como parâmetro orientador das interações dialógicas em linha com o que vem sendo exposto.

Haverá circunstâncias sociais e políticas em que a situação ideal de diálogo já não orienta as interações reais, isto é, podemos nos encontrar numa situação em que as pessoas (cidadãos) já não se encontram imersas numa autêntica situação de diálogo. São frequentes as situações em que o oponente simplesmente se recusa ao diálogo "como se fosse uma planta”, ou, cinicamente, se recusa ao diálogo para não ser refutado, ou para manter a situação social, política ou econômica existente, ou, ainda, instrumentaliza o discurso, para seus interesses. Mesmo nestas situações, todavia, as condições ideais de diálogo ainda nos proporcionam elementos para identificar a violência incompatível com a civilidade da desobediência civil. Nas condições mencionadas, o agente moral (o desobediente não violento) deve atuar no sentido de que as condições ideais de diálogo venham a existir, evitando que a situação existente piore ainda mais. Nesta

ação, executar ele mesmo a mudança proposta, posto que, ainda segundo Habermas, remetendo-se a Ralf Dreier, a não violência não exclui sempre elementos de coação e é compatível com a pressão psíquica e a restrição da liberdade de movimentos de terceiros. 
situação podemos imaginar hipóteses em que as mudanças se efetuem sem o acordo do oponente e, inclusive, que seja necessário imobilizá-lo. Estas ações, se realizadas com o objetivo e a convicção de que o oponente, no futuro, virá a concordar com as mudanças pretendidas, podemos ainda considerá-las não violentas e concordes com a civilidade da desobediência civil. Se, no entanto, são realizadas com o objetivo de apartar o oponente de um futuro acordo ou, inclusive, para eliminá-lo, estas ações já não serão mais não violentas e também terão perdido o caráter de civis, embora ainda possam ser, eventualmente, justificáveis ético-politicamente a partir de outros critérios.

O conceito de violência esboçado nos permite igualmente distinguir mais satisfatoriamente entre desobediência civil e desobediência revolucionária. $\mathrm{O}$ desobediente civil procura a mudança social por meio do diálogo com a comunidade política, ainda que possa utilizar, tanto ao dialogar quanto para provocar o oponente para o diálogo, certas ações de pressão ou de coerção - “interinfluências positivas”. O desobediente civil, no entanto, parte do pressuposto de que já comparte ou ainda comparte com os adversários suficientes convicções que lhe permitam um procedimento de diálogo, e obter, com este diálogo, uma solução consensuada, aceitável para todos, para determinada questão relacionada à convivência social, objeto de disputa. A questão em disputa pode ser, inclusive, profunda, estrutural, dizendo respeito a uma norma de convivência de nível constitucional, por exemplo.

Por esta razão, isto é, por crer na mudança consensuada a partir do que ainda comparte com os demais integrantes da sociedade ou por crer que pode despertar nos oponentes convicções que, de momento, eles não têm e que permitirão a mudança consensuada, o desobediente civil não imporá sua solução, nem excluirá nenhum participante no diálogo. Nesse sentido, o desobediente civil poderia pretender, e conseguir, verda- 
deiras “revoluções pacíficas”, considerada a profundidade (radicalidade) das mudanças, como mudanças constitucionais mesmo que vedadas no Direito vigente, sem transformar-se em desobediente revolucionário.

O desobediente revolucionário, ao contrário, parte do pressuposto, equivocadamente ou não, de que o "mundo compartido" na sociedade em que vive, e dada a profundidade ou características das questões da convivência social problematizadas ou postas em questão, não permite soluções dialogadas. Por esta razão, o desobediente revolucionário entende, convencido como está da correção de sua proposta, que somente lhe resta a imposição de sua solução, excluindo, portanto, uma parte da sociedade, na busca cooperativa da norma ou das condições de convivência corretas para seu estabelecimento. Em palavras de Galtung, pode-se ressaltar que o desobediente revolucionário exercerá sobre seus oponentes uma “interinfluência negativa”, uma violência, em suma. Além disto, é de supor que nesta situação as divergências que separam as partes em conflito sejam profundas e irreconciliáveis. Neste sentido, pode-se afirmar que o desobediente revolucionário apela à violência, e as mudanças sociais que propugna são profundas e radicais.

\section{CONSIDERAÇÕES FINAIS}

Ao longo do presente artigo, abordamos o fenômeno da violência, seu conceito, suas espécies ou variantes e sua inter-relação com a desobediência civil. A partir do conceito de (não)violência, distinguimos entre desobediência civil e desobediência revolucionária (ou criminal). A questão orientadora da nossa pesquisa foi: Que violência torna incivil uma desobediência?

A partir das considerações feitas ao longo do artigo, podemos agora concluir que a violência que torna incivil uma desobediência é aquela que encerra em si um desejo de matar o adversário. O adversário, aqui, são os oponentes políticos nas disputas pela melhor forma de convivência social, 
porque um dos significados (não tematizado neste artigo) do civil da desobediência civil é cidadã (política). Este desejo de matar o oponente pode não se concretizar, mas a vontade de eliminá-lo, de exclúi-lo ou reduzi-lo ao silêncio é mais forte do que a de chegar a um acordo com ele. $\mathrm{O}$ insulto, a humilhação, a tortura, além do homicídio, são formas do intento de dar morte, de violentar, de atacar a dignidade do adversário. Retomando Jean-Marie Muller, violentar é sempre fazer calar. Privar ao homem de sua palavra já é privá-lo de sua vida. Dizer a alguém que se cale, não escutar seus argumentos, excluí-lo da comunidade de diálogo, para usar termos próprios da linguagem da ética discursiva habermasiana, seria uma violência equivalente à de dar morte a este alguém. Ou, mandar calar seria ainda pior do que dar morte, porque faz sofrer e o sofrimento seria mais temível que a morte, porque fazer sofrer implica ódio, que deseja a morte com sofrimento.

É neste sentido o pensamento de Hannah Arendt (1967, p. 22-23), para quem a violência guarda uma relação com a imposição do silêncio, razão pela qual deve ser considerada um fenômeno marginal na esfera da política, na qual se enquadram as ações de desobediência civil. O homem, como ser político, está dotado com o poder da palavra. Foi nos campos de concentração dos regimes totalitários onde tudo e todos silenciaram.

Seriam violentos, em suma, os atos que supõem, por seus métodos e/ ou objetivos, não uma apelação ao sentido de justiça da maioria, do governo, para que modifiquem suas posturas - uma tentativa de convencer e converter -, mas a exclusão do oponente com a imposição da solução pretendida, realizando os próprios agentes (desobedientes) a mudança reivindicada.

\section{REFERÊNCIAS}

ARENDT, Hannah. Sobre la revolución. Trad. Pedro Bravo. Madrid: Editorial Revista de Occidente, 1967.

COSTA, Nelson Nery. Teoria e realidade da desobediência civil. 2. ed. Rio de Janeiro: Forense, 2000. 
ETXEBERRIA, Xabier. El lugar del diálogo en la gestión positiva de los conflictos y el caso vasco. Un estudio en el marco de las "Investigaciones sobre paz y conflictos”. In: BILBAO, Galo et al. Conflictos, violencia y diálogo. El caso vasco. Bilbao: Universidad de Deusto, 2004. p. 31-93.

GALTUNG, Johan. Direitos humanos. Uma nova perspectiva. Trad. Margarida Fernandes. Lisboa: Instituto Piaget, 1998.

. O caminho é a meta: Gandhi hoje. Trad. Humberto Mariotti. São Paulo: Ed. Palas Athena, 2003a.

. Paz por medios pacíficos. Paz y conflicto., Desarrollo y civilización. Bilbao: Bakeaz, 2003b.

. Cadeias de violência: elogio da mediação política. In: Zero Hora. Suplemento especial de julho de 2004, "Fórum 2004. Barcelona 9 de maio - 26 de setembro de 2004”. Porto Alegre, p. 28-29.

GANDHI, Mahatma. Somos todos irmãos: reflexões autobiográficas. Trad. Euclides Luiz Calloni. São Paulo: Ed. Paulus, 1998.

HABERMAS, Jürgen. La desobediencia civil. Piedra de toque del Estado democrático de Derecho. In: . Ensayos políticos. 3. ed. Barcelona: Ediciones Península, 1997. p. 51-71.

MALEM SEÑA, Jorge F. Concepto y justificación de la desobediencia civil. Barcelona: Ariel, 1990.

MULLER, Jean-Marie. O princípio de não violência. Percurso filosófico. Trad. Maria Fernanda Oliveira. Lisboa: Instituto Piaget, 1998.

RAWLS, John. Uma teoria da justiça. São Paulo: Martins Fontes, 1997.

UGARTEMENDIA ECEIZABARRENA, Juan Ignacio. La desobediencia civil en el Estado constitucional democrático. Madrid: Marcial Pons, 1999.

WELLMAN, Carl. La desobediencia civil. In: . Morales y éticas. Trad. Jesús Rodríguez Marín. Madrid: Editorial Tecnos, 1982.

WOODCOCK, George. Gandhi. Trad. R. Fernandez Calvo. Barcelona: Planeta de Agostini, 1995. 